\title{
ZLATÁ ZÁUŠNICE Z HOMOL (OKR. ČESKÉ BUDĚJOVICE) JAKO DOKLAD KONTAKTU JIŽNÍCH ČECH S KARPATSKOU KOTLINOU VE STARŠÍ DOBĚ BRONZOVÉ
}

\author{
O N D ̌̌ E C H V O K A - JA N JOH N
}

\begin{abstract}
Gold Earring from Homole (Dist. České Budějovice) as the Evidence of Contacts Between South Bohemia and Carpathian Basin in the Early Bronze Age. The article deals with a new unique find of a gold earring of the so-called Transylvanian type from Homole in South Bohemia. A detailed typological-chronological analysis is supplemented by an XRF analysis of golden alloy. The earring can be considered as evidence of either a direct or at least mediated influence from the Carpathian Basin to Bohemia in the Early Bronze Age.
\end{abstract}

Keywords: South Bohemia, Carpathian Basin, Early Bronze Age, Transylvanian type jewel, gold, XRF analysis.

\section{ÚVOD}

Jižní Čechy jsou ve starší době bronzové považovány za region, stojící na pomezí několika významných středoevropských kultur - únětické na severu, straubinské na jihu a jihozápadě a středodunajských kultur na jihovýchodě (Hájek 1954; Havlice 2000; Chvojka 2015). Bez nadsázky lze tak jihočeskou oblast považovat za kontaktní území, výrazně napojené na dálkový obchod s důležitými komoditami (zejména alpská měd’ a sůl, severský jantar či pazourek). O intenzivních dálkových kontaktech jižních Čech svědčí celá řada importů - měděných ingotů i výrobků, z nichž některé mají původ v dosti vzdálených oblastech (Chvojka/Hlásek/Menšík 2017). $\mathrm{V}$ našem př́spěvku, věnovanému významnému životnímu jubileu prof. Jozefa Bátory, zaměříme pozornost na doklady vztahů jižních Čech do širšího prostoru Karpatské kotliny - do oblasti, k poznání jejíhož vývoje v eneolitu a především ve starší době bronzové náš jubilant významně přispěl. Soustředíme se přitom na nejnovější nález zlatého šperku z Homol a na jeho zevrubnou analýzu.

\section{ZLATÁ ZÁUŠNICE \\ TZV.SEDMIHRADSKÉHO TYPU Z HOMOL (OKR. ČESKÉ BUDĚJOVICE)}

\section{Nálezové okolnosti a popis záušnice}

Dne 22. 2. 2020 objevil spolupracovník Jihočeského muzea, Ing. Zbyněk Kadlec, náhodně zlatý artefakt, který neprodleně ohlásil a odevzdal do muzejní archeologické sbírky. Následně místo spolu s nálezcem navštívil O. Chvojka a provedl jeho dokumentaci a zaměření pomocí GPS (48.9355936N,
14.4239414E). Záušnice se nacházela mimo původní kontext, $\mathrm{v}$ ornici, $\mathrm{v}$ hloubce $\mathrm{cca} 10 \mathrm{~cm}$ pod současným povrchem, $45 \mathrm{~m}$ SV od kóty $426 \mathrm{~m}$ na JZ okraji obce, $5 \mathrm{~m}$ západně od sloupu elektrického vedení, 470 m JZ od kaple v centru obce Homole. Nálezová situace zatím nebyla archeologicky ověřena.

\section{Popis nálezu:}

Zlatá záušnice hruškovitého tvaru se zpětně stočenými konci. Vyrobena je z tenkého drátu o průměru $1 \mathrm{~mm}$, který se směrem $\mathrm{k}$ oběma koncům zesiluje až na průměr $3 \mathrm{~mm}$. Výška 31 mm, šířka max. 20 mm, hmotnost 12,753 g. Nález je uložen v archeologické sbírce Jihočeského muzea v Českých Budějovicích pod inv. č. A 39.006 (obr. 1).

Interpretaci ojedinělého šperku z jihočeských Homol ztěžuje absence jeho bližšího nálezového kontextu. $\mathrm{V}$ prostoru nálezu bylo sice $\mathrm{v}$ posledních letech Z. Kadlecem objeveno několik dalších pravěkých artefaktů, vesměs se však jedná o blíže nedatovatelnou (patrně halštatskou) pravěkou keramiku a pak o několik zlomků bronzových předmětů, datovatelných většinou do mladší doby bronzové (několik zlomků jehlic, zlomek srpu). Do starší doby bronzové zde zatím prokazatelně náleží pouze zde publikovaný zlatý artefakt a také již v minulosti nalezený kadlub na odlévání mušlovitých závěsků a několik keramických zlomků; jejich přesná lokalizace není sice známá, zhruba se však jednalo o sledovaný prostor (Blažek/Ernée/Smejtek 1998, 190, 191).

V blízkém okolí nálezu se přibližně v první polovině 20. století nacházela pískovna, která byla následně rekultivována. Nelze tedy vyloučit ani sekundární přemístění zde analyzovaného šperku. Zlatou záušnici tak zatím považujeme za ojedinělý nález, přičemž bez provedení podrobnějšího archeologického výzkumu nelze $\mathrm{v}$ tuto chvíli rozhodnout, byla-li původně součástí pohřební výbavy, depotu či byla ztracena na soudobém sídlišti. 


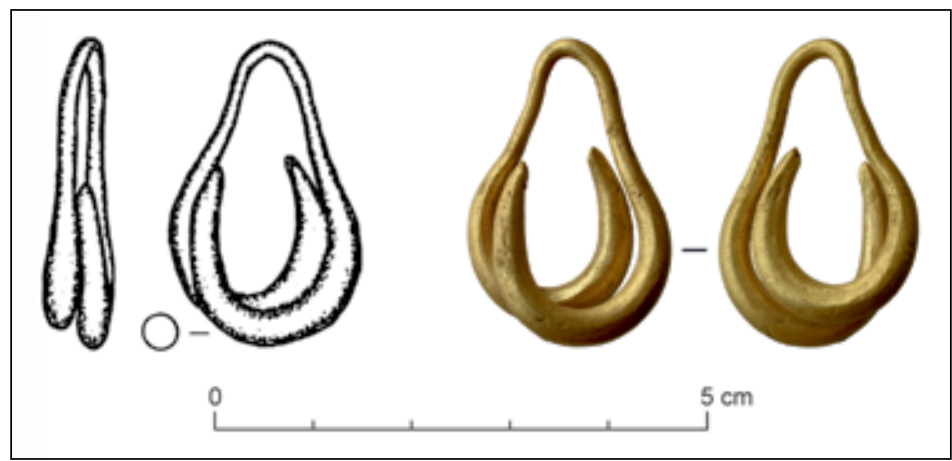

Obr. 1. Homole (okr. České Budějovice). Zlatá záušnice (kresba T. Kolegar; foto J. John).

\section{Archeologická analýza}

Záušnice z Homol představuje jediný zlatý jihočeský nález artefaktu, označovaného v Karpatské kotlině a ve středodunajské oblasti jako záušnice, náušnice či závěsek sedmihradského nebo též sibiňského typu (Bátora 2018, 173; Hásek 1960; Mozsolics 1973, 51; Schmidt 1904, 615-624; Vladár 1973, 263-265; k terminologii kriticky: Benkovsky-Pivovarová/Chropovský 2015, 62). Jedná se o poměrně širokou a variabilní skupinu šperků z bronzu i zlata oválného, srdcovitého až hruškovitého tvaru, které lze z hlediska způsobu ukončení rozdělit do dvou základních variant $-\mathrm{s}$ jednoduše se překrývajícími konci a se zpětně otočeným ramenem (zvané též lod'kovité; Nováček 2010, 45; Olexa/Nováček 2013, 38). Podle technologie výroby bývají odlišovány dvě základní skupiny: z drátu/tyčinky a duté z plechu. V Karpatské kotlinějsou plechové varianty považovány za mladší, náležející již střední době bronzové (Mozsolics 1968, 20; Neugebauer-Maresch/Neugebauer 1988-1989, 127). Homolský exemplář patří do první skupiny, $\mathrm{k}$ jednouché tyčinkovité variantě hruškovitého tvaru s překrývajícími se konci, které S. Stuchlík a J. Stuchlíková označují jako variantu A1 (Stuchlík/Stuchlíková 1996, 153). Podle jiné typologie, publikované E. Zahariou, patř́ náš šperk do varianty B1b, tj. oválného základního tvaru z tyčinky a s rozšířenými konci (Zaharia 1959, 109, 110, obr. 2: 2, 3). Homolský šperk každopádně představuje jednu variantu sedmihradských závěsků/záušnic, přičemž $\mathrm{v}$ dalším textu shrneme i informace o dalších variantách, a to i bronzových či měděných.

Rozšíření tohoto typu šperku je koncentrováno ve východní části Karpatské kotliny, zejména v prostředí otomanské kultury (Bátora 2006, 207, 208, obr. 147; Hänsel 1968, 113, 114; Meller 2014, 627, 628, obr. 17; Vladár 1973, 263, 264). Jeho původ je však hledán ve východoevropské oblasti, zejména v regionech severního Kavkazu (Bátora 1982, 262; 2018, 173; Vladár 1973, 264). Objevily se ovšem i ná- zory o původu šperku sedmihradského typu ve 3. tisíciletí př. Kr. v Mezopotámii (Stejskalová 1999). Výskyt závěsků či záušnic sedmihradského typu je ovšem prokázán i v západnějších oblastech střední Evropy, přičemž za periferní území jejich výskytu se obvykle považuje Morava a východní Rakousko (Stuchlík 1997, 166). Obdobné šperky byly nalezeny dokonce i v šachtových hrobech v Mykénách (Schránil 1921, 58), přičemž se objevil názor, že tam byly přineseny barbarskými princeznami ze severu jako součást jejich věna (Bouzek 2015, 45, obr. 11).

Jádrem územního rozšsírení šperků sedmihradského typu, jak ostatně naznačuje i jejich pojmenování, je východní část Karpatské kotliny, zahrnující Sedmihradsko, východní Mad’arsko a východní Slovensko (obr. 2). Nálezům z východního Madarska a Sedmihradska se zde vzhledem k jejich značnému množství a k horší dostupnosti literatury podrobněji věnovat nebudeme (základní přehledy viz např. Bóna 1975, 135, 159, 175; Hänsel 1968, 113, 114, soupis 118-120; Kacsó 2006, 76-80; Meller 2014, 685-689, soupis 2; Mozsolics 1968, 19-23). Výskyt těchto šperků $\mathrm{v}$ depotech na Zakarpatské Ukrajině zmapoval J. Kobal' (2000, 58, 59, tab. 1: A), soupis nálezů ze Srbska a Chorvatska přinesl H. Meller (2014, soupis 2).

Na východním Slovensku náležejí nejstarší nálezy šperků sedmihradského typu již do koštanské kultury, tj. do závěru stupně BA1 a na počátek A2 a obdobně jsou datovány i některé nálezy z přilehlého mad’arského horního Potisí (Bátora 1982, 262; 2000, 411; 2018, 173; Vladár 1973, 263). V prostředí otomanské kultury jsou zlaté záušnice/závěsky sedmihradského typu doloženy jak v depotech (napřs. Barca: Hájek 1954, obr. 254-256; Spišský Štvrtok: Oravkinová/Vladár 2019; Vladár 2012; Vladár/Oravkinová 2015), tak i v hrobech. Na pohřebišti v Nižné Myšli se běžně vyskytovaly sedmihradské (sibiňské) záušnice jak bronzové (v počtu 266), tak i zlaté (21 ks; Olexa/Nováček 2012, 275; 2013, 38, 39, obr. 32; 33; 2015, 34, 35, obr. 12; 13; 2017, 33, 34, obr. 10: 1-10). Uniká- 


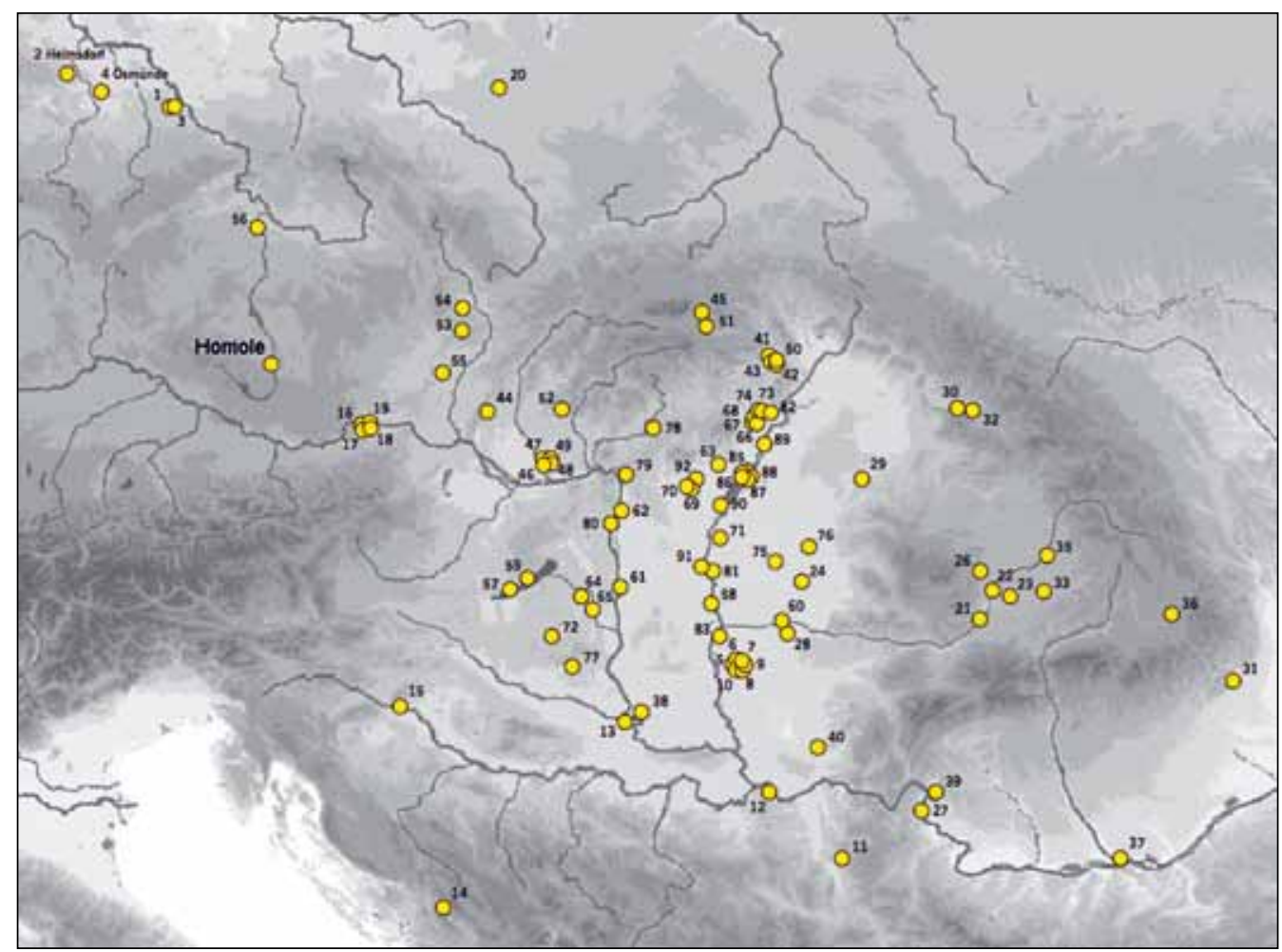

Obr. 2. Rozšíření zlatých šperků sedmihradského typu ve střední Evropě (podle H. Mellera 2014, obr. 17; čísla lokalit odpovídají soupisu v citované práci; doplnil J. John).

tem je pak imitace záušnice sedmihradského typu $\mathrm{z}$ březové kůry, která byla nalezena $\mathrm{v}$ obětní studni v Gánovcích u Popradu (Bátora 2018, 367, obr. 290: 6).

Bronzové záušnice sedmihradského typu jsou doloženy i na severním Slovensku, jak dokládá soubor devíti exemplářù z Liskovské jeskyně (Sliacka 2015). Další jeskynní nález tř́i obdobných bronzových záušnic pochází z Bronzovej jeskyně u Spišské Nové Vsi (Soják/Mihál' 2007, 234, 235, obr. 4).

Na jihozápadním Slovensku se nejstarší záušnice sedmihradského typu, vyrobené z bronzu, objevují již v prostředí klasické fáze únětické kultury (Bátora 2000, 409; Benkovsky-Pivovarová/Chropovský 2015, 62, obr. 120). V prostředí mad’arovské kultury $\mathrm{v}$ témže regionu jsou tyto šperky sledovaného typu známy z několika pohřebních lokalit: např̀. jedna celá pochází z hrobu 184 z Jelšovců (Bátora 2000, 103, 409-411, tab. 17: 11), zlomky celkem čtyř exemplářů ze dvou hrobů ze Sládkovičova (Toč́k 1979, 187, 189, tab. 73: 15-17, 29, 30). Všechny jsou vyrobeny z bronzu (srov. též Benkovsky-Pivovarová/Chropovský 2015, 62). Sedmihradské náušnice (záušnice) ze zlata jsou pak početně zastoupeny $\mathrm{v}$ hrobech hurbanovské skupiny (Bátora 2000, 410; Dušek 1969, tab. 1: 14; Točík 1979, tab. 95:3, 16). Bronzové šperky tohoto typu jsou na jihozápadním Slovensku doloženy i v prostředí karpatské mohylové kultury na počátku střední doby bronzové (pohřebiště Dolný Peter: Dušek 1969, 52, obr. 5: 7).
Z Moravy lze jako nejbližší tvarovou analogii k homolskému nálezu uvést zlatou náušnici z výbavy mužského kostrového hrobu z Lednice na Břeclavsku, objeveného již v r. 1895 (Hásek 1960, 107, obr. 14: 2; Tihelka 1953, 276, obr. 21: 3). Podobný, dnes bohužel ztracený exemplář, měl pocházet $z$ únětického hrobu v Hradčanech (Stuchlík/Stuchlíková 1996, 153; Tihelka 1953, 276). K variantě se zpětnou kličkou patří dva zlaté závěsky z Dobročkovic (Lehrberger et al. 1997, 297, tab. 50: M25, M26; Rzehak 1899, 2-7, obr. 1, 2; Tihelka 1953, 276, obr. 14: 5). Z nedávné doby pak pochází jeden celý a jeden neúplný závěsek sedmihradského typu ze Stolové hory u Klentnice (Stuchlík 2018, obr. 4: 5, 6). Z Moravy přitom existují i doklady měděných či bronzových šperků tohoto typu (např. Velké Pavlovice: Stuchlík/Stuchlíková 1996, obr. 10: 9), některé menší zlomky ovšem nemusely být dosud rozpoznány a správně klasifikovány. Mladší vývojový derivát těchto šperků pak představuje zdobený plechový dutý exemplář z mohylového hrobu stupně BB1 z Tulešic (Lehrberger et al. 1997, 298, tab. 50: M59).

V Dolním Rakousku byly zlaté nálezy, mj. i několik náležejících do kategorie sedmihradského šperku, zveřejněny z pohřebiště Franzhausen I (Neugebauer-Maresch/Neugebauer 1988-1989). Další doklady jednotlivých exemplářru pocházejí z hrobů v Gemeinlebarn, Würnitz a Eggenburg (Schubert 1974, 76, tab. 22: 5; 27: 6, 7). 
Z Čech byl dosud znám jediný zlatý šperk sedmihradského typu - záušnice se zpětným ramenem $\mathrm{z}$ hrobu č. $5 \mathrm{z}$ Turska, která byla interpretována jako pravděpodobný import ze sedmihradské oblasti (Moucha 1997, 163, tab. 20: Č346). Mimo to je z Čech známo i několik závěsků/záušnic sedmihradského typu z bronzu či mědi (Bartelheim 1998, 64, mapa 57, 147; Hásek 1955, 665; Schránil 1921, 57-60, obr. 11; Stejskalová 1999, obr. 3: 1-3). Tři pocházejí z hrobu č. $28 \mathrm{v}$ Úněticích, dva $z$ hrobu č. $2 \mathrm{v}$ Tursku, jeden jistý a tři zlomky potenciálně z dalších z hrobu 11 ve Zvoleněvsi, tři možné zlomky ze Svrkyně a jeden závěsek z Brodců nad Jizerou (Hásek 1960, 105, 106, obr. 15). Na rozdíl od „hruškovitých“ tvarů jihovýchodního původu jsou tyto bronzové či měděné šperky oválné, I. Hásek je proto považoval za lokální únětické výrobky (Hásek 1960, 110, 111). Jediné z Čech nám známé měděné/bronzové záušnice tohoto typu, které mají náznak hruškovitého tvaru, pocházejí z nálezů (snad hrobových) z Kamýku u Velkých Př́lep (Moucha 1996, 27, obr. 1: 6-9).

Výjimečně jsou zlaté šperky sedmihradského typu uváděny i ze severních částí střední Evropy. Z Polska lze zmínit např. dnes zničený závěsek z Weronikopole (Hásek 1960, 107, obr. 14: 3) nebo masivní zlatý šperk z Komarówa (Makarowicz 2010, obr. 3.17: 26). V Německu najdeme analogické dva exempláře k homolskému šperku ve známé „,knížecí" mohyle v Helmsdorfu (Hásek 1960, 107, obr. 14: 5; Meller 2014, obr. 15); další stejný šperk z Bornitz/ Oschatz (Hásek 1960, 107, obr. 14: 4; Meller 2014, 685) je dnes bohužel ztracen. V Osmünde byly nalezeny dvě záušnice sedmihradského typu se zpětnou kličkou (Meller 2014, 626-628, obr. 16).

$\mathrm{Z}$ podaného přehledu vyplývá, že s výskytem zlatých, bronzových i měděných šperků sedmihradského typu je třeba počítat $\mathrm{v}$ prủběhu celé starší doby bronzové, byt jejich většina spadá do její mladší fáze (BA2; Stuchlík/Stuchlíková 1996, 153). Nejstarší exempláře jsou ve střední Evropě uváděny již z mladého eneolitu (Mozsolics 1968, 19). Na východním Slovensku a $\mathrm{v}$ přilehlé části dnešního Mad’arska a Sedmihradska jsou doloženy zhruba od závěru stupně BA1 (Vladár 1973, 263). V Karpatské kotlině pak přežívají hluboko do střední doby bronzové, kdy se však většinou vyskytují ve variantě s kličkovitými konci (Hänsel 1968, 114, př́loha 5). Zároveň zde mizí sedmihradské šperky vyrobené $\mathrm{z}$ bronzu a zůstávají jen ty vyrobené ze zlata (Olexal Nováček 2015, 34, 35).

Šperky tohoto typu bývají v literatuře označovány za záušnice, náušnice či závěsky. Většinou jsou interpretovány jako spínadla vlasů, ozdoba pokrývky hlavy či závěsky na čelenky (Olexa/Nováček 2012, 275), jejich př́ípadná funkce jako náušnic bývá většinou zpochybňována (Olexa/Nováček 2013, 39). Mimo to v nich také bývá spatřován artefakt magického, společensko-prestižního či dokonce monetárního významu (Kacsó 2006, 89). V kostrových hrobech bývají nacházeny $\mathrm{v}$ prostoru hlavy - většinou na spánkových kostech (Olexa/Nováček 2013, 38, 39; 2017, 33). Častý je jejich výskyt ve dvojicích, mohou se však objevit i ve 4 exempláŕích $\mathrm{v}$ jednom hrobě (Bóna 1975, 159) - zde je ovšem zejména v př́ípadě zlatých exemplářù nutné počítat s možným vykrádáním, tj. redukcí dnešního počtu artefaktů (srov. Neugebauer-Maresch/Neugebauer 1988-1989, 129, 130). Za zmínku stojí hrob č. 115 z Nižné Myšle, kde byly nalezeny dvě tvarově i rozměrově identické záušnice, z nichž jedna byla zlatá a druhá bronzová (Olexal Nováček 2013, 117, tab. 54: 3, 4). V hrobě č. 153 na téže lokalitě byla jedna zlatá záušnice nalezena společně s dalšími 9 bronzovými záušnicemi sedmihradského typu (Olexa/Nováček 2013, tab. 71: 2, 3).

Šperky sedmihradského typu bývají součástí ženských i mužských hrobových výbav. Poměrně často se objevují v mužských hrobech (Olexa/Nováček 2013, 39), v nich ovšem jen $\mathrm{v}$ jednom exempláři (Neugebauer-Maresch/Neugebauer 1988-1989, 130); u pohřbů žen bývají ve dvojicích, přičemž někdy jsou oba exempláře stejné, jindy je jedna záušnice levotočivá a druhá naopak (Benkovsky-Pivovarovál Chropovský 2015, 62; Olexa/Nováček 2015, 35). Naopak z rumunského pohřebiště v Sărata-Monteoru je uváděna přítomnost těchto šperků pouze $\mathrm{v}$ ženských hrobech (Zaharia 1959, 105).

Šperky sedmihradského typu se ve střední Evropě hojně vyskytují v hrobech i v depotech, výjimečně i jednotlivě na sídlištích (nejnovější přehled viz Meller 2014, soupis 2). V Mad'arsku i v Sedmihradsku se $\mathrm{v}$ depotech vyskytují především zlaté exempláře (Bóna 1975, 159, tab. 198; Kacsó 2006, 76-80; Mozsolics 1968, 19), dosahujících mnohdy i značného počtu (Jászdózsa-Kápolnahalom - 37 ks: Stanczik/ Tárnoki 1992, 124, obr. 81; Hangopuszta - 62 ks, Pécs/?/ - 124 ks: Meller 2014, 688, 689). Podobně je tomu i na východním Slovensku, kde v depotech z Barci či Spišského Štvrtku rovněž dominují zlaté šperky sedmihradského typu (Hájek 1954; Oravkinová/Vladár 2019; Vladár 2012).

Zlatý šperk z jihočeských Homol tedy jednoznačně spadá do široké kategorie šperků sedmihradského typu. Vzhledem k absenci původní nálezové situace a doprovodných artefaktů jej můžeme jen obecně datovat do průběhu starší doby bronzové, snad do jejích mladších fází. Zajímavé je přitom metrické srovnání s některými dalšími zlatými šperky sedmihradského typu (tabela 1). Z hlediska své výšky homolský šperk nijak nevybočuje $\mathrm{z}$ běžného rámce. Mimořádná je však jeho hmotnost 12,75 g, která výrazně převyšuje hmotnosti většiny dalších zvážených exemplářuo, pohybující se většinou v rozmezí $1-7 \mathrm{~g}$. Větší hodnoty 
Tabela 1. Příklady různých variant zlatých závěsků/záušnic sedmihradského (sibinského) typu, jejich základních nálezových okolností a metrických hodnot. Uvedeny pouze vybrané příklady celých exemplárù z České republiky, Slovenska, Rakouska, Německa a Polska. Datace jsou v některých případech orientační. Výška - max. vnější rozměr předmětu. Otazník - neuvedený údaj.

\begin{tabular}{|c|c|c|c|c|c|c|c|}
\hline Země & Lokalita & Kontext & Datace & $\begin{array}{l}\text { Výška } \\
\text { (mm) }\end{array}$ & $\begin{array}{c}\text { Hmot- } \\
\text { nost } \\
\text { (g) }\end{array}$ & Poznámka & Literatura \\
\hline Čechy & Homole & ojed. nález & BA & 31 & 12,75 & - & v tomto článku \\
\hline Čechy & Tursko & hrob 5 & BA2 & 10 & 5,95 & - & Moucha 1997, 163 \\
\hline Morava & Dobročkovice & $?$ & BA2 & 26 & 28,21 & - & Lehrberger et al. 1997, M25 \\
\hline Morava & Dobročkovice & $?$ & BA2 & 28 & 31,8 & - & Lehrberger et al. 1997, M26 \\
\hline Morava & Hradčany & hrob & BA & $?$ & $?$ & nezvěstný & Tihelka 1953, 276 \\
\hline Morava & Klentnice & depot? & BA2 & $?$ & $?$ & - & Stuchlík 2018, obr. 4: 6 \\
\hline Morava & Klentnice & depot? & BA2 & $?$ & $?$ & $\begin{array}{l}\text { neúplný } \\
\text { exemplář }\end{array}$ & Stuchlík 2018, obr. $4: 5$ \\
\hline Morava & Lednice & kostrový hrob & BA2 & $?$ & 3,1 & - & Tihelka 1953, obr. $21: 3$ \\
\hline SK & Bajč & hrob 26 & BA2 & $?$ & $?$ & - & Točík 1979, tab. XCV: 7 \\
\hline SK & Bajč & hrob 32 & BA2 & $?$ & $?$ & - & Točík 1979, tab. XCVI: 8 \\
\hline SK & Košice-Barca & depot & BA2-BB1 & $?$ & $?$ & $\begin{array}{c}\text { celkem } \\
22 \mathrm{ks}\end{array}$ & Hájek 1954 \\
\hline SK & Nesvady & hrob 11 (dětský) & BA2 & 22 & 4,78 & - & Dušek 1969, 14, tab. 1: 14 \\
\hline SK & Nesvady & hrob 46 (dospělý) & BA2 & 22 & 4,88 & - & Dušek 1969, 21, tab. 5:10 \\
\hline SK & Nesvady & hrob 50 (dospělý) & BA2 & $?$ & $?$ & - & Dušek 1969, 21, tab. 5: 12 \\
\hline SK & Nesvady & hrob 89 (dospělý) & BA2 & $?$ & 3,2 & - & Dušek 1969, 30-31, tab. 10: 9 \\
\hline SK & Nesvady & hrob 89 (dospělý) & BA2 & $?$ & 3,34 & - & Dušek 1969, 30-31, tab. 10: 10 \\
\hline SK & Nesvady & hrob 89 (dospělý) & BA2 & $?$ & 3,41 & - & Dušek 1969, 30-31, tab. 10: 12 \\
\hline SK & Nesvady & hrob 89 (dospělý) & BA2 & $?$ & 3,54 & - & Dušek 1969, 30-31, tab. 10: 13 \\
\hline SK & Nižná Myšla & hrob 3 & BA2 & $?$ & 3,48 & - & Olexa/Nováček 2013, tab. 3: 8 \\
\hline SK & Nižná Myšla & hrob 11 & BA2 & $?$ & 6,77 & - & Olexa/Nováček 2013, tab. 7: 7 \\
\hline SK & Nižná Myšla & hrob 115 & BA2 & $?$ & 3,34 & - & Olexa/Nováček 2013, tab. 54: 3 \\
\hline SK & Nižná Myšla & hrob 153 & BA2 & $?$ & 5,3 & - & Olexa/Nováček 2013, tab. 71: 2 \\
\hline SK & Nižná Myšla & hrob 184 & BA2 & $?$ & 5,25 & - & Olexa/Nováček 2013, tab. 86: 2 \\
\hline SK & Nižná Myšla & hrob 197 & BA2 & $?$ & 3,9 & - & Olexa/Nováček 2013, tab. 93: 3 \\
\hline SK & Nižná Myšla & hrob 386 & BA3 & $?$ & 2,4 & - & Olexa/Nováček 2015, tab. 71: 9 \\
\hline SK & Nižná Myšla & hrob 386 & BA3 & $?$ & 2,25 & - & Olexa/Nováček 2015, tab. 71: 10 \\
\hline SK & Nižná Myšla & hrob 404 & BA3 & $?$ & 3,8 & - & Olexa/Nováček 2015, tab. 87: 5 \\
\hline SK & Nižná Myšla & hrob 404 & BA3 & $?$ & 3,3 & - & Olexa/Nováček 2015, tab. 87: 6 \\
\hline SK & Nižná Myšla & hrob 440 & BA3 & $?$ & 1,55 & - & Olexa/Nováček 2015, tab. 117: 1 \\
\hline
\end{tabular}


Tabela 1. Pokračování.

\begin{tabular}{|c|c|c|c|c|c|c|c|}
\hline Země & Lokalita & Kontext & Datace & $\begin{array}{l}\text { Výška } \\
(\mathrm{mm})\end{array}$ & $\begin{array}{c}\text { Hmot- } \\
\text { nost } \\
\text { (g) }\end{array}$ & Poznámka & Literatura \\
\hline SK & Nižná Myšla & hrob 440 & BA3 & $?$ & 1,45 & - & Olexa/Nováček 2015, tab. 117: 2 \\
\hline SK & Nižná Myšla & hrob 570 & BA3 & ? & 2,6 & - & Olexa/Nováček 2017, tab. 61: 5 \\
\hline SK & Nižná Myšla & hrob 570 & BA3 & ? & 1,5 & - & Olexa/Nováček 2017, tab. 61: 6 \\
\hline SK & Nižná Myšla & hrob 595 & BA3 & $?$ & 1 & - & Olexa/Nováček 2017, tab. 78: 3 \\
\hline SK & Nižná Myšla & hrob 595 & BA3 & $?$ & 1,4 & - & Olexa/Nováček 2017, tab. 78: 4 \\
\hline SK & Nižná Myšla & hrob 655 & BA3 & $?$ & 1,2 & - & Olexa/Nováček 2017, tab. 124: 1 \\
\hline SK & Nižná Myšla & hrob 655 & BA3 & $?$ & 1,2 & - & Olexa/Nováček 2017, tab. 124: 2 \\
\hline SK & Nižná Myšla & hrob 700 & BA3 & $?$ & 1,8 & - & Olexa/Nováček 2017, tab. 141: 4 \\
\hline SK & Nižná Myšla & hrob 700 & BA3 & ? & 2,2 & - & Olexa/Nováček 2017, tab. 141: 5 \\
\hline SK & Nižná Myšla & hrob 774 & BA3 & ? & 2,3 & - & Olexa/Nováček 2017, tab. 181: 1 \\
\hline SK & Spišský Štvrtok & $\begin{array}{l}\text { obj. 5/68, dep. } \\
\text { v nádobě }\end{array}$ & BB1 & 30 & 7,9 & - & Oravkinová/Vladár 2019, obr. 4: 4 \\
\hline SK & Spišský Štvrtok & $\begin{array}{l}\text { obj. } 5 / 68, \text { dep. } \\
\text { v nádobě }\end{array}$ & BB1 & 27 & 4,7 & - & Oravkinová/Vladár 2019, obr. 4: 5 \\
\hline SK & Spišský Štvrtok & $\begin{array}{l}\text { obj. } 5 / 68 \text {, dep. } \\
\text { v nádobě }\end{array}$ & BB1 & 23 & 2,5 & - & Oravkinová/Vladár 2019, obr. 4: 6 \\
\hline SK & Spišský Štvrtok & $\begin{array}{l}\text { obj. 5/68, dep. } \\
\text { v nádobě }\end{array}$ & BB1 & 28 & 5,6 & - & Oravkinová/Vladár 2019, obr. 4: 7 \\
\hline SK & Spišský Štvrtok & $\begin{array}{l}\text { obj. } 5 / 68 \text {, dep. } \\
\text { v nádobě }\end{array}$ & BB1 & 26 & 3 & - & Oravkinová/Vladár 2019, obr. 4: 8 \\
\hline SK & Spišský Štvrtok & $\begin{array}{l}\text { obj. 5/68, dep. } \\
\text { v nádobě }\end{array}$ & BB1 & 25 & 3,4 & - & Oravkinová/Vladár 2019, obr. 4: 9 \\
\hline SK & Spišský Štvrtok & $\begin{array}{l}\text { obj. 5/68, dep. } \\
\text { v skříńce }\end{array}$ & BB1 & 35 & 3,9 & - & Oravkinová/Vladár 2019, obr. 5: 4 \\
\hline SK & Spišský Štvrtok & obj. 9/68, depot & BB1 & 14 & 3,3 & - & Oravkinová/Vladár 2019, obr. 6: 5 \\
\hline SK & Spišský Štvrtok & obj. 9/68, depot & BB1 & 24 & 2,5 & - & Oravkinová/Vladár 2019, obr. 6: 6 \\
\hline SK & Spišský Štvrtok & obj. 9/68, depot & BB1 & 28 & 5,7 & - & Oravkinová/Vladár 2019, obr. 6: 7 \\
\hline SK & Spišský Štvrtok & obj. 9/68, depot & BB1 & 31 & 14 & zdobený & Oravkinová/Vladár 2019, obr. 6: 8 \\
\hline SK & Spišský Štvrtok & obj. 9/68, depot & BB1 & 25 & 5 & - & Oravkinová/Vladár 2019, obr. 6: 9 \\
\hline SK & Spišský Štvrtok & obj. 9/68, depot & BB1 & 29 & 4 & - & Oravkinová/Vladár 2019, obr. 6: 10 \\
\hline SK & Spišský Štvrtok & obj. 9/68, depot & BB1 & 30 & 5,6 & - & Oravkinová/Vladár 2019, obr. 6: 11 \\
\hline SK & Spišský Štvrtok & obj. 9/68, depot & BB1 & 27 & 4 & - & Oravkinová/Vladár 2019, obr. 6: 12 \\
\hline SK & Spišský Štvrtok & obj. 9/68, depot & BB1 & 26 & 5,4 & - & Oravkinová/Vladár 2019, obr. 6: 13 \\
\hline SK & Spišský Štvrtok & obj. 19/70, depot & BB1 & 33 & 4,4 & - & Oravkinová/Vladár 2019, obr. 8: 5 \\
\hline SK & Spišský Štvrtok & obj. 24/71, depot & BB1 & 40 & 24,1 & $\begin{array}{l}\text { ze } 2 \text { plášttů, } \\
\text { zdobený }\end{array}$ & Oravkinová/Vladár 2019, obr.9: 12 \\
\hline SK & Spišský Štvrtok & obj. 26/71, depot & BB1 & 44 & 27,9 & $\begin{array}{l}\text { ze } 2 \text { plášt'ů, } \\
\text { zdobený }\end{array}$ & Oravkinová/Vladár 2019, obr. 11: 1 \\
\hline SK & Spišský Štvrtok & obj. 26/71, depot & BB1 & 25 & 3,9 & - & Oravkinová/Vladár 2019, obr.11: 2 \\
\hline
\end{tabular}


Tabela 1. Pokračování.

\begin{tabular}{|c|c|c|c|c|c|c|c|}
\hline Země & Lokalita & Kontext & Datace & $\begin{array}{l}\text { Výšḱa } \\
\text { (mm) }\end{array}$ & $\begin{array}{c}\text { Hmot- } \\
\text { nost } \\
\text { (g) }\end{array}$ & Poznámka & Literatura \\
\hline A & Franzhausen I & hrob 16 & BA2 & 60 & 1,1 & - & $\begin{array}{c}\text { Neugebauer-Maresch/Neugebauer } \\
\text { 1988-1989, tab. 1: } 5\end{array}$ \\
\hline A & Franzhausen I & hrob 92 & BA2 & 45 & 2,4 & - & $\begin{array}{c}\text { Neugebauer-Maresch/Neugebauer } \\
\text { 1988-1989, tab. 10: } 22\end{array}$ \\
\hline A & Franzhausen I & hrob 587 & BA2 & 80 & 4,7 & - & $\begin{array}{c}\text { Neugebauer-Maresch/Neugebauer } \\
\text { 1988-1989, tab. 3: } 5\end{array}$ \\
\hline A & Franzhausen I & hrob 595 & BA2 & 12 & 4,4 & - & $\begin{array}{c}\text { Neugebauer-Maresch/Neugebauer } \\
\text { 1988-1989, tab. 4: } 6\end{array}$ \\
\hline A & Franzhausen I & hrob 853 & BA2 & 12 & 4,7 & - & $\begin{array}{c}\text { Neugebauer-Maresch/Neugebauer } \\
\text { 1988-1989, tab. 5: } 7\end{array}$ \\
\hline PL & Weronikopole & $?$ & $?$ & $?$ & $?$ & zničen & Hásek 1960, 107, obr. 14: 3 \\
\hline $\mathrm{DE}$ & $\begin{array}{l}\text { „Bornitzl } \\
\text { Oschatz“ }\end{array}$ & ojedinělý nál. & ? & 28 & ? & ztracen & Hásek 1960, 107, obr. 14: 4 \\
\hline $\mathrm{DE}$ & Helmsdorf & knižecí mohyla & BA2 & 21 & 9,8 & - & Meller 2014, 694 \\
\hline $\mathrm{DE}$ & Helmsdorf & knížecí mohyla & BA2 & 21 & 10,2 & - & Meller 2014, 694-695 \\
\hline $\mathrm{DE}$ & Osmünde & hrob & BA2 & 12 & 6,51 & - & Meller 2014, 696 \\
\hline $\mathrm{DE}$ & Osmünde & hrob & BA2 & 11,3 & 6,28 & - & Meller 2014, 696 \\
\hline
\end{tabular}

jsme zjistili pouze u dvou závěsků z Dobročkovic (28,2 a 31,8 g), které jsou však jiné varianty (Lehrberger et al. 1997, tab. 50: M25-26), a u dvou artefaktů z depotů v objektech 24/71 a 26/71 ze Spišského Štvrtku (24,1 a $27,9 \mathrm{~g}$ ), které jsou však jedinečné jak z hlediska své konstrukce, tak i výzdoby (Oravkinová/Vladár 2019, 100, obr. 9: 12; 11: 1). Podobnou hodnotu 9,8 a 10,2 g mají dvě k šperku z Homol i tvarově téměř identické záušnice z Helmsdorfu (Meller 2014, 694, 695, obr. 15) a rovněž jedna záušnice $\mathrm{z}$ depotu $\mathrm{z}$ objektu 9/68 ze Spišského Štvrtku (14 g), která je navíc i zdobená (Oravkinová/Vladár 2019, 93, obr. 6: 8).

\section{Slitina artefaktu z Homol a otázka původu zlata}

Prvkové složení slitiny bylo zjištováno pouze povrchovou rentgenfluorescenční metodou za pomoci ručního XRF spektrometru Niton XL2 GOLDD. Jedná se o rychlou, nedestruktivní a dostupnou metodu, která ale neumožňuje zachycení stopových prvků, jež bývají ve slitinách drahých kovů obsaženy ve velmi malém množství (např. Pt, Pd). Právě stopové prvky se mohou v budoucnu ukázat jako klíčové při zjištování provenience zlata, jejich analýz je však zatím poměrně malé množství - viz např́ ozdoby z bohatých hrobů starší doby bronzové ve východním Německu, analyzované pomocí LA-ICP-MS (Lockhoff/Pernicka 2014).

Výsledek měření šperku z Homol ukázal, že jde o slitinu zlata a stř́bra, v níž zlato výrazně převažuje (tabela 2). Zlaté ozdoby starší doby bronzové bývají zpravidla vyrobené ze směsi těchto dvou kovù, přičemž vyhodnocení větších souborů analýz ukázalo dvě skupiny zastoupení stř́ibra ve slitině, jednu kolem 11 \% a druhou kolem 25 \% (Frána 1997, 164; cf. Lockhoffl Pernicka 2014, 226). Artefakt z Homol tedy evidentně patří do skupiny ozdob s nižším obsahem Ag.

Množství stříbra v záušnicích sedmihradského typu má obecně poměrně velkou variabilitu. Kupř́kladu záušnice $\mathrm{z}$ „knížecí" mohyly v Helmsdorfu, které jsou velmi podobné nálezu z Homol, obsahují jen 6,6 a 6,8 \% Ag (Lockhoff/Pernicka 2014, 228), naopak záušnice z hrobu 184 v Nižné Myšli má mít 44 \% podíl Ag (Mihok/Olexa/Briančin 1996, 6).

Tabela 2. Homole. Výsledek XRF analýzy zlatého šperku. Hodnoty jsou zprůměrovány ze dvou měření a uvedeny $\mathrm{v}$ hmotnostních procentech.

\begin{tabular}{|c|c|c|c|c|c|}
\cline { 2 - 6 } \multicolumn{1}{c|}{} & Au & Ag & Cu & Hg & Fe \\
\hline Homole & 87,61 & 11,74 & 0,13 & 0,13 & 0,25 \\
\hline
\end{tabular}


Různé zastoupení stříbra může odpovídat využívání odlišných ložisek zlata, jejich přesnější lokalizace však není tímto způsobem možná. Roli mohla hrát i preference specifických zlatých slitin pro konkrétní typy artefaktů (např. ve výbavách bohatých mohyl Leubingen a Helmsdorf je prokázáno využitíjiného typu zlaté slitiny pro ozdoby vlasů a jiného pro jehlice a ostatní ozdoby: Lockhoff/Pernicka 2014, 230, 231).

V oblasti Balkánu a Podunají nepochybně hrálo významnou úlohu zlato ze sedmihradských ložisek, pro nějž jsou typické vysoké obsahy stříbra, zpravidla nad 20 \% (Hartmann 1970, 40). U nálezů sedmihradských šperků z centrálních lokalit otomanské kultury na východním Slovensku je ale připouštěna jejich výroba z lokálních zdrojů, a to nejen na základě odlišného chemického složení ve srovnání se sedmihradskými zdroji (Olexa/Nováček 2013, 40, 41), ale i nálezů polotovarů $\mathrm{k}$ výrobě záušnic ze Spišského Štvrtku (Vladár/Oravkinová 2015, 449, 450). Rovněž některé nálezy zlatých záušnic tohoto typu z oblasti únětické kultury vykazují nižší obsahy stř́bra a mohou odpovídat zlatu z jiných než sedmihradských zdrojů (kromě výše zmíněného Helmsdorfu např. moravské nálezy z Lednice a Dobročkovic: Lehrberger et al. 1997, 297, 298, tab. 50: M25, M31). Zároveň se však na našem území setkáváme i s vyššími obsahy Ag nad $20 \%$, kam spadá dosud jediný český zlatý zástupce sedmihradského typu šperku z Turska (Lehrberger et al. 1997, 274, tab. 20: Č346) a další exemplár̆ z moravských Dobročkovic (Lehrberger et al. 1997, 297, tab. 50: M26).
Pro výrobu zlatých ozdob sedmihradského typu tedy můžeme na základě variability přírodní příměsi stříbra předpokládat využivání různých ložisek, bohužel bez možnosti jejich přesné identifikace. Jelikož provenienci zlata zpravidla nelze s jistotou prokázat, nemůžeme prozatím ani spolehlivě určit, jestli jsou jednotlivé exempláře nalezené mimo předpokládanou oblast jejich výroby importy nebo lokálními napodobeninami.

\section{ZÁVĚR}

Zlatý šperk z Homol můžeme považovat za doklad bud' přímého, nebo alespoň zprostředkovaného vlivu z prostředí Karpatské kotliny do Čech (srov. Bátora 2006, 207, 208; Hásek 1960, 110; Vladár 1973, 263-265). Pro srovnání lze uvést, že dva analogické exempláře $\mathrm{z}$ „knížecího“ hrobu z Helmsdorfu jsou rovněž interpretovány jako importy z Karpatské kotliny, zatímco dvě záušnice jiné varianty z Osmünde jsou považovány za lokální napodobeniny (Meller 2014, 627, 628).

Nově objevený zlatý šperk tak potvrzuje význam jižních Čech jako oblasti, stojící na křižovatce různých dálkových vlivů, $\mathrm{k}$ nimž bezesporu patřily kontakty s širší oblastí Karpatské kotliny. Přestože obě tato území dělí od sebe několikasetkilometrová vzdálenost, nebyly vzájemné vztahy žádnou výjimkou. Svým drobným dílem k tomuto poznání přispívá i nález z Homol.

\section{LITERATURA}

Bartelheim 1998 - M. Bartelheim: Studien zur böhmischen Aunjetitzer Kultur - Chronologische und chorologische Untersuchungen. UPA 46. Bonn 1998.

Bátora 1982 - J. Bátora: Ekonomicko-sociálny vývoj východného Slovenska v staršej dobe bronzovej. Slovenská archeológia 30, 1982, 249-314.

Bátora 2000 - J. Bátora: Das Gräberfeld von Jelšovce/Slowakei. Ein Beitrag zur Frühbronzezeit im nordwestlichen Karpatenbecken. Teil 1-2. PAS 16/1-2. Kiel 2000.

Bátora 2006 - J. Bátora: Štúdie ku komunikácii medzi strednou a východnou Európou v dobe bronzovej. Bratislava 2006.

Bátora 2018 - J. Bátora: Slovensko v staršej dobe bronzovej. Bratislava 2018.

Benkovsky-Pivovarová/Chropovský 2015 - Z. Benkovsky-Pivovarová/B. Chropovský: Grabfunde der frühen und beginnenden mittleren Bronzezeit in der Westslowakei. Teil 2. Nitra 2015.

Blažek/Ernée/Smejtek 1998 - J. Blažek/M. Ernée/L. Smejtek: Die bronzezeitlichen Gußformen in Nordwestböhmen. Beiträge zur Ur- und Frühgeschichte Nordwestböhmens 3. Most 1998.

Bóna 1975 - I. Bóna: Die mittlere Bronzezeit Ungarns und ihre südöstlichen Beziehungen. Budapest 1975.
Bouzek 2015 - J. Bouzek: Únětická kultura a civilizace východního Středomoří, Egypta a Mezopotámie. In: J. Bátora/P. Tóth (ed.): Ked' bronz vystriedal med'. Zborník príspevkov z XXIII. medzinárodného sympózia „Staršia doby bronzová v Čechách, na Morave a na Slovensku". Nitra - Bratislava 2015, 39-50.

Dušek 1969 - M. Dušek: Bronzezeitliche Gräberfelder in der Südwestslowakei. Bratislava 1969.

Frána 1997 - J. Frána: Materialanalysen des frühbronzezeitlichen Goldes aus Böhmen. In: G. Lehrberger/ J. Fridrich/R. Gebhard/J. Hrala (Hrsg.): Das prähistorische Gold in Bayern, Böhmen und Mähren: Herkunft - Technologie - Funde. Památky archeologické. Supplementum 7. Praha 1997, 164-165.

Hájek 1954 - L. Hájek: Zlatý poklad v Barci u Košic. Archeologické rozhledy 6, 1954, 584-587, 610-612.

Hänsel 1968 - B. Hänsel: Beiträge zur Chronologie der mittleren Bronzezeit im Karpatenbecken. Bonn 1968.

Hartmann 1970 - A. Hartmann: Prähistorische Goldfunde aus Europa. Studien zu den Anfängen der Metallurgie 3. Berlin 1970 .

Hásek 1955 - I. Hásek: Českomoravské zlaté nálezy z doby bronzové. Archeologické rozhledy 7, 1955, 659-676. 
Hásek 1960 - I. Hásek: Oválné závěsky sedmihradského typu v únětickém prostředí. Acta Universitatis Carolinae, Philosphica et Historica 3. Sborník prací k poctě 60 . narozenin akademika Jana Filipa. Praha 1960, 105-112.

Havlice 2000 - J. Havlice: Kontakty mezi jižními Čechami a středním Podunajím ve starší době bronzové. Diplomová práce. Filozofická fakulta Univerzity Karlovy. Praha 2000. Nepublikované.

Chrojka 2015 - O. Chvojka: Chronologie und Kulturen der südböhmischen Bronzezeit und Ihre Parallelisierung zu den Donaugebieten und Karpatenbecken. In: R. E. Németh/B. Rezi (eds.): Bronze Age Chronology in the Carpathian Basin. Proceedings of the International Colloquium from Targu Mures 2-4 October 2014. Targu Mures 2015, 9-22.

Chvojka/Hlásek/Menšík 2017 -O. Chvojka/D. Hlásek/P. Menšík: Mitteleuropäische Kontakte der südböhmischen Bronzezeit. Fines Transire 26, 2017, 133-145.

Kacsó 2006 - C. Kacsó: Bronzefunde mit Goldgegenständen im Karpatenbecken. In: J. Kobal' (Hrsg.): Bronzezeitliche Depotfunde - Problem der Interpretation. Materialien der Festkonferenz für Tivodor Lehoczky zum 175. Geburtstag. Ushhorod, 5.-6. Oktober 2005. Užgorod 2006, 76-123.

Kobal' 2000 - J. Kobal: Bronzezeitliche Depotfunde aus Transkarpatien (Ukraine). PBF XX/4. Stuttgart 2000.

Lehrberger et al. 1997 - G. Lehrberger/J. Fridrich/R. Gebhard/J. Hrala (Hrsg.): Das prähistorische Gold in Bayern, Böhmen und Mähren: Herkunft - Technologie - Funde. Band I-II. Památky archeologické. Supplementum 7. Praha 1997.

Lockhoff/Pernicka 2014 - N. Lockhoff/E. Pernicka: Archaeometallurgical investigations of Early Bronze Age gold artefacts from central Germany including gold from the Nebra hoard. In: H. Meller/R. Risch/E. Pernicka (Hrsg.): Metalle der Macht - frühes Gold und Silber. Tagungen des Landesmuseums für Vorgeschichte Halle 11/I-II. Halle (Saale) 2014, 223-236.

Makarowicz 2010 - P. Makarowicz: Trzciniecki krag kulturowy - wspólnota pogranicza Wschodu i Zachodu Europy. Poznań 2010.

Meller 2014 - H. Meller: Die neolithischen und bronzezeitlichen Goldfunde Mitteldeutschlands - Eine Übersicht. In: H. Meller/R. Risch/E. Pernicka (Hrsg.): Metalle der Macht - Frühes Gold und Silber. Tagungen des Landesmuseums für Vorgeschichte Halle 11/I-II. Halle (Saale) 2014, 611-716.

Mihok/Olexa/Briančin 1996 - L'. Mihok/L. Olexa/J. Briančin: Spôsob výroby zlatých predmetov z doby bronzovej z Nižnej Myšle. Archeologia technica 10, 1996, 5-15.

Moucha 1996 - V. Moucha: Zu den Beziehungen zwischen Bayern und Böhmen während der älteren Bronzezeit. In: K. Schmotz/M. Zápotocká (Hrsg.): Archäologische Arbeitsgemeinschaft Ostbayern/West- und Südböhmen. 5. Treffen 1995 in Sulzbach-Rosenberg. Espelkamp 1996, 26-32.

Moucha 1997 - V. Moucha: 6.4.2.1 Böhmen. In: G. Lehrberger/J. Fridrich/R. Gebhard/J. Hrala (Hrsg.): Das prähistorische Gold in Bayern, Böhmen und Mähren: Herkunft - Technologie - Funde. Památky archeologické. Supplementum 7. Praha 1997, 154-164.

Mozsolics 1968 - A. Mozsolics: Goldfunde des Depotfundhorizontes von Hajdúsámson. Bericht der Römisch-Germanischen Kommission 46-47, 1968, 1-76.
Mozsolics 1973 - A. Mozsolics: Bronze- und Goldfunde des Karpatenbeckens. Budapest 1973.

Neugebauer-Maresch/Neugebauer 1988-1989 - Ch. Neugebauer-Maresch/J. W. Neugebauer: Goldobjekte aus den Frühbronzezeitnekropolen Franzhausen 1 und 2 und Gemeinlebarn F. Mitteilungen der Anthropologischen Gesellschaft in Wien 118-119, 1988-1989, 101-134.

Nováček 2010 - T. Nováček: Pohrebisko otomansko-füzesabonyskej kultúry na lokalite Nižná Myšla - nekeramické pamiatky staršieho horizontu. Diplomová práce. Filozofická fakulta Masarykovy univerzity. Brno 2010. Nepublikované.

Olexa/Nováček 2012 - L. Olexa/T. Nováček: Praveké zlato z Nižnej Myšle. In: R. Kujovský/V. Mitáš (ed.): Václav Furmánek a doba bronzová. Zborník $k$ 70. narodeninám. Nitra 2012, 273-278.

Olexa/Nováček 2013 - L. Olexa/T. Nováček: Pohrebisko zo staršej doby bronzovej v Nižnej Myšli. Katalóg I (hroby 1 - 310). Nitra 2013.

Olexa/Nováček 2015 - L. Olexa/T. Nováček: Pohrebisko zo staršej doby bronzovej v Nižnej Myšli. Katalóg II (hroby 311 - 499). Nitra 2015.

Olexa/Nováček 2017 - L. Olexa/T. Nováček: Pohrebisko zo staršej doby bronzovej v Nižnej Myšli. Katalóg III (hroby 500 - 792). Nitra 2017.

Oravkinová/Vladár 2019 - D. Oravkinová/J. Vladár: The Phenomenon of Hoarding at the Fortified Settlement in Spišský Štvrtok. In: K. P. Fischl/T. L. Kienlin (eds.): Beyond Divides - The Otomani-Füzesabony Phenomenon. Current Approaches to Settlement and Burial in the North-eastern Carpathian Basin and Adjacent Areas. UPA 345. Bonn 2019, 83-119.

Rzehak 1899 - A. Rzehak: Ueber einige merkwürdige Vor- und frühgeschichtliche Alterthümer Mährens. Separatendruck. Zeitschrift des Vereins für die Geschichte Mährens und Schlesiens 3/4, 1899, 1-31.

Schmidt 1904 - H. Schmidt: Troja - Mykene - Ungarn. Zeitschrift für Ethnologie 36, 1904, 608-656.

Schránil 1921 - J. Schránil: Studie o vzniku kultury bronzové $v$ Čechách. Praha 1921.

Schubert 1974 - E. Schubert: Studien zur frühen Bronzezeit an der mittleren Donau. Bericht der Römisch-Germanischen Kommission 54, 1973, 1-105.

Sliacka 2015 - S. Sliacka: Kolekcia drobných bronzových šperkov z Liskovskej jaskyne. Zborník SNM 109. Archeológia 25, 2015, 31-35.

Soják/Mihál 2007 - M. Soják/F. Mihál: Interdisciplinárna spolupráca pri výskume speleoarcheologických lokalít na Slovensku (so zameraním na východné Slovensko). Ve službách archeologie 1, 2007, 231-251.

Stanczik/Tárnoki 1992 - I. Stanczik/J. Tárnoki: Jászdózsa-Kápolnahalom. In: W. Meier-Arendt (Hrsg.): Bronzezeit in Ungarn. Forschungen in Tell-Siedlungen an Donau und Theiss. Frankfurt am Main 1992, 120-127.

Stejskalová 1999 - D. Stejskalová: Možná cesta drobného šperku z Blízkého východu do střední Evropy. Archeologie ve středních Čechách 3, 1999, 87-92.

Stuchlík 1997 - S. Stuchlík: 6.4.2.2 Mähren. In: G. Lehrberger/J. Fridrich/R. Gebhard/J. Hrala (Hrsg.): Das prähistorische Gold in Bayern, Böhmen und Mähren: Herkunft - Technologie - Funde. Památky archeologické. Supplementum 7. Praha 1997, 165, 166.

Stuchlík 2018 - S. Stuchlík: Nové typy zlatých vlasových ozdob z Moravy. In: J. Bátora/R. Kujovský/M. Ruttkay/ 
J. Vladár (ed.): Anton Točík. Legenda slovenskejarcheológie. Nitra 2018, 161-168.

Stuchlík/Stuchlíková 1996 - S. Stuchlík/J. Stuchlíková: Aunjetitzer Gräberfeld in Velké Pavlovice, Südmähren. Prähistorische Zeitschrift 71, 1996, 123-175.

Tihelka 1953 - K. Tihelka: Moravská únětická pohřebiště. Památky archeologické 44, 1953, 229-328.

Točík 1979 - A. Točík: Výčapy-Opatovce a d'alšie pohrebiská zo staršej doby bronzovej na juhozápadnom Slovensku. Nitra 1979.

Vladár 1973 - J. Vladár: Osteuropäische und mediterrane Einflüsse im Gebiet der Slowakei während der Bronzezeit. Slovenská archeológia 21, 1973, 253-357.

Vladár 2012 - J. Vladár: Depoty bronzových a zlatých výrobkov na výšinnom opevnenom sídlisku otomanskej

Rukopis přijat 9. 6. 2020

Translated by Jan John

doc. Mgr. Ondřej Chvojka, Ph.D.

Jihočeská univerzita v Českých Budějovicích

Archeologický ústav

Branišovská 31a

CZ - 37005 České Budějovice

ochvojka@jcu.cz kultúry v Spišskom Štvrtku. In: R. Kujovský/V. Mitáš (ed.): Václav Furmánek a doba bronzová. Zborník k 70. narodeninám. Nitra 2012, 383-395.

Vladár/Oravkinová2015 -J. Vladár/D. Oravkinová: Tezaurácia bronzových a zlatých predmetov na opevnenom sídlisku v Spišskom Štvrtku. In: J. Bátora/P. Tóth (ed.): Ked' bronz vystriedal med' Zborník príspevkov z XXIII. medzinárodného sympózia „Staršia doby bronzová v Čechách, na Morave a na Slovensku“. Nitra - Bratislava 2015, 433-452.

Zaharia 1959 - E. Zaharia: Die Lockenringe von Sărata-Monteoru und ihre typlogischen und chronologischen Beziehungen. Dacia NS 3, 1959, 103-134.

\title{
Gold Earring from Homole (Dist. České Budějovice) as the Evidence of Contacts Between South Bohemia and Carpathian Basin in the Early Bronze Age
}

\author{
Ondřej Chvojka - Jan John
}

SUMMARY

In February 2020, a unique find of the gold earring was found near the village of Homole in South Bohemia (Fig. 1). Although it is an isolated find without an archaeological context, based on the typological-chronological analysis, it can be classified as a jewellery of the so-called Transylvanian type. These artefacts were particularly widespread in the Carpathian Basin during the Early Bronze Age (Fig. 2; Table 1); on the other hand, in Bohemia they are very rare (cf. Hásek 1960). The earring was analysed

Fig. 1. Homole (dist. České Budějovice). Gold earring (drawing by T. Kolegar; photo by J. John).

Fig. 2. Distribution of gold jewellery of the Transylvanian type in Central Europe (after H. Meller 2014, fig. 17; the numbers of sites correspond to the list in the cited work; edited by J. John).

Table 1. Examples of different variants of gold pendants/ earrings of the Transylvanian (Sibinian) type, their
Jihočeská univerzita v Českých Budějovicích

Archeologický ústav

Branišovská 31a

CZ - 37005 České Budějovice

jjohn@jcu.cz 